\section{Evaluation of morphological changes in pharynx with dynamic CT and MRI in snoring patients}

\author{
FATMA AKTAȘ ${ }^{1}$, TURAN AKTAȘ ${ }^{2}$, ZAFER ÖZMEN ${ }^{1}$, \\ HÜSEYIN AKAN ${ }^{1}$, TOLGA AKSÖZ ${ }^{3}$, AYŞEGÜL ALTUNKAŞ ${ }^{1}$
}

\section{ABSTRACT}

Background: Identifying the craniofacial abnormalities that cause snoring and the narrowest area of the upper airway creating obstructions can help to determine the proper method of treatment. Aim: To identify the factors that can cause snoring and the areas of the airway that are the most likely to collapse with upper airway imaging. Material and Methods: Axial pharynx examinations with CT (computerized tomography) and magnetic resonance imaging (MRI) were performed to 38 patients complaining of snoring and 12 patients who did not complain of snoring. The narrowest areas of nasopharynx, hypophraynx, oropharynx, bilateral para-pharyngeal fat pad and para-pharyngeal muscle thickness were measured. Results: In snoring patients, the narrowest part of the upper airway was the retro-palatal region in the oropharynx, as measured with both imaging methods. When patients with and without snoring were compared, the former that a higher body mass index and neck diameter and a narrower oropharynx area. In dynamic examinations, we determined that as para-pharyngeal muscle thickness increased, medial-lateral airway diameter and the oropharynx area decreased. Conclusions: The narrowest section of the airway is the retro-palatal region of the oropharynx, measured both with CT and MRI.

(Rev Med Chile 2016; 144: 1125-1133)

Key words: Magnetic Resonance Imaging; Oropharynx; Snoring; Tomography X-Ray Computed.

\section{Anomalías morfológicas de la faringe en roncadores}

Antecedentes: La identificación de las anomalías craneofaciales que causan el ronquido es importante para decidir la terapia adecuada. Objetivo: Identificar los factores que causan el ronquido y las zonas de la vía aérea superior que son más susceptibles de colapsar, usando imágenes. Material y Métodos: Se efectuaron exámenes axiales de la faringe con tomografía computada (TC) y resonancia magnética $(R M)$ en 38 pacientes que roncaban y 12 que no lo hacían. Se determinaron las zonas más estrechas de la nasofaringe, hipofaringe, orofaringe y el grosor del tejido adiposo y musculatura parafaríngeos. Resultados: En los pacientes que roncaban la zona más estrecha de la vía aérea superior fue la zona retro-palatal en la orofaringe. Los pacientes roncadores tenían un indice
'Gaziosmanpaşa University

Faculty of Medical School,

Department of Radiology.

${ }^{2}$ Gaziosmanpaşa University

Faculty of Medical School,

Department of Pulmonary

Diseases.

${ }^{3}$ Balıkesir State Hospital,

Department of Radiology.

Funding: No funding was received for this research.

Ethical Approval: In our university no ethical approval was required for this study. Informed patient consent was sufficient. Informed consent: Informed consent was obtained from all individual > participants included in the study.

The authors declare that they

have no conflict of interest.

Recibido el 4 de abril de 2016, aceptado el 27 de julio de 2016 .

Correspondencia a: M.D Fatma AKTAS,

Gaziosmanpasa University, Faculty of Medicine, Department of Radiology, 60100 Tokat, Turkey. fatmakokcu79@hotmail.com 
Morphological abnormalities of the pharynx in snoring individuals - F. Aktaş et al

de masa corporal y diámetro cuello mayores y un área orofaríngea menor. En los exámenes dinámicos observamos que a medida que el grosor de los músculos parafaríngeos aumentó, disminuyó el área medial y lateral de la vía aérea y el área de la orofaringe. Conclusiones: La zona más estrecha de la vía aérea superior es la región retropalatal de la orofaringe, medida tanto con TC como con RM.

S noring is caused by the narrowing of airways when soft tissue layers relax. It is also caused by vibrations of soft tissues during sleep. Snoring is a symptom of obstructive sleep apnea syndrome (OSAS), a condition that can cause serious health complications. The main complications resulting from snoring and OSAS are cerebrovascular issues, hypertension, cardiac arrhythmia, coronary artery disease, corpulmonale and stroke, all of which can lead to death.

Identifying the craniofacial abnormalities that cause snoring and the narrowest area of the upper airway creating obstructions can help determine the proper method of treatment. A large number of studies have been carried out on this issue so far and evaluation of anatomical pathologies and pharyngeal morphology have been made by CT or MRI. However, which imaging method has been more effective as a guiding method to treatment has not been discussed. The aim of this study is to contribute to the literature by carrying out both MRI and CT in the same patient group.

\section{Materials and Methods}

Thirty-eight patients without lung problems or complications with sinonasal pathology applied to the Department of Otolaryngology and the Department of Chest Diseases at Ondokuz Mayis University's Faculty of Medicine for inclusion in the study. Of these patients, 12 were women, and 26 were men. These individuals ranged between 17 and 60 years (with an average age of 45). These individuals, all of whom complained of complications with snoring, made up the patient group. In addition to the 38 participants in the patient group, data acquired through the evaluation of 14 individuals ( 10 men and 4 women) applying to CT forroutine neck examination by CT and 12 individuals ( 7 men and 5 women) were included in a control group. The members of the control group did not have complaints with snoring. The patients in both groups were informed of the study procedures, and their approval was obtained. Neck diameter was measured using a tape rule from the point at which the cricoid cartilage was the most prominent under the thyroid cartilage.

\section{Imaging methods and parameters}

Computerized tomography examination was performedby multislice computed tomography with 16 line detector (Toshiba TSX-101A, Aquillon 16 Slice, Tochigi, Japan). Unenhanced routine axial imaging was performed from the superior of nasopharynx to the end of epiglottis. Imaging parameters were Kv: $120 \mathrm{~mA}: 150$ section thickness: $2 \mathrm{~mm}$ and interslice distance: $2 \mathrm{~mm}$.

The images were transposed to another workstation. Narrowest nasopharynx and hypopharynx cross-sectional areas were carried out from axial images. In lateral scannogram, the narrowest oropharynx level was determined as the section on which posterior airway is the narrowest. Dynamic examination was performed at this level to identify changes based on respiration phase, and the narrowest and the widest areas of oropharynx (Figures 1, 2). Imaging parameters were kv:120 ma: 50 , table propagation rate: 0 section thickness: $2 \mathrm{~mm}$ scanning span: $19,8 \mathrm{sec}$.

MRI was used to obtain images of the patients' airway. A device with 1.5 tesla units of magnetic field power (Magnetom Symphony Quantum, Siemens Medical Systems, Erlangen, Germany) was used. The imaging process was completed using a head and neck phase array coil. T2 Weighted (W) axial images were taken from the hard palate to the epiglottis. The most crucial areas to be examined were identified field of view (FOV). The examination parameters were as follows: Time repetition(TR) of $5460 \mathrm{msn}$, time echo (TE) of $103 \mathrm{msn}$, FOV of 232, number of excitations NEX of 1 , section thicknesses of $5 \mathrm{~mm}$, and interslice distances of $0 \mathrm{~mm}$.

Using the images, midsagittal dynamic examination was performed by setting the sagittal plane that passes directly through the midline (Figures $3,4)$. In dynamic examinations, $\mathrm{T} 2 \mathrm{~W}$ gradient 


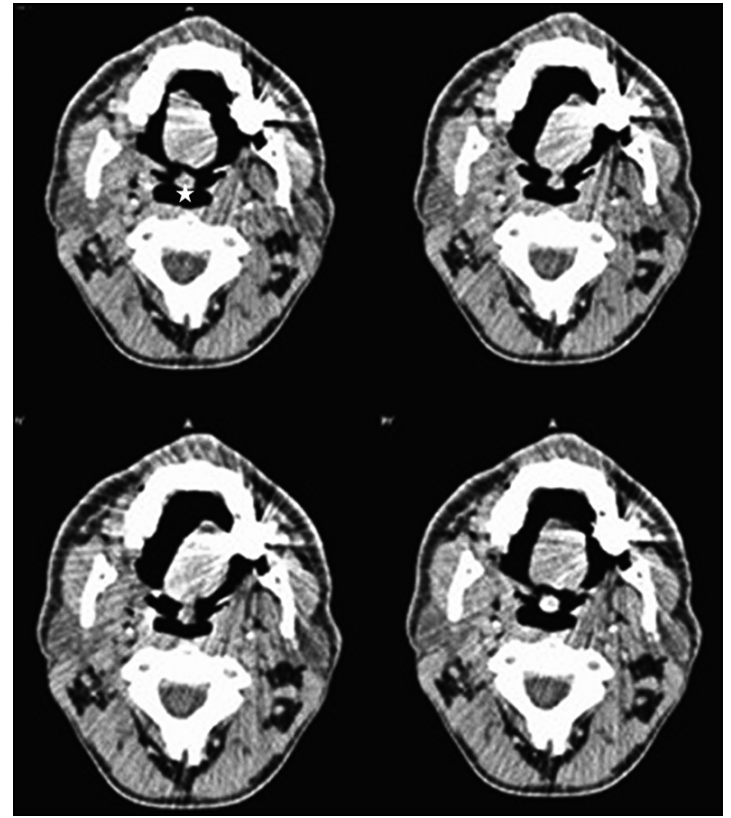

Figure 1. Axial dynamic CT examination of a control patient at the oropharynx's narrowest level. The airway was not narrow (asterix) and there was not any significant change in airway calibration based on the dynamic examination.

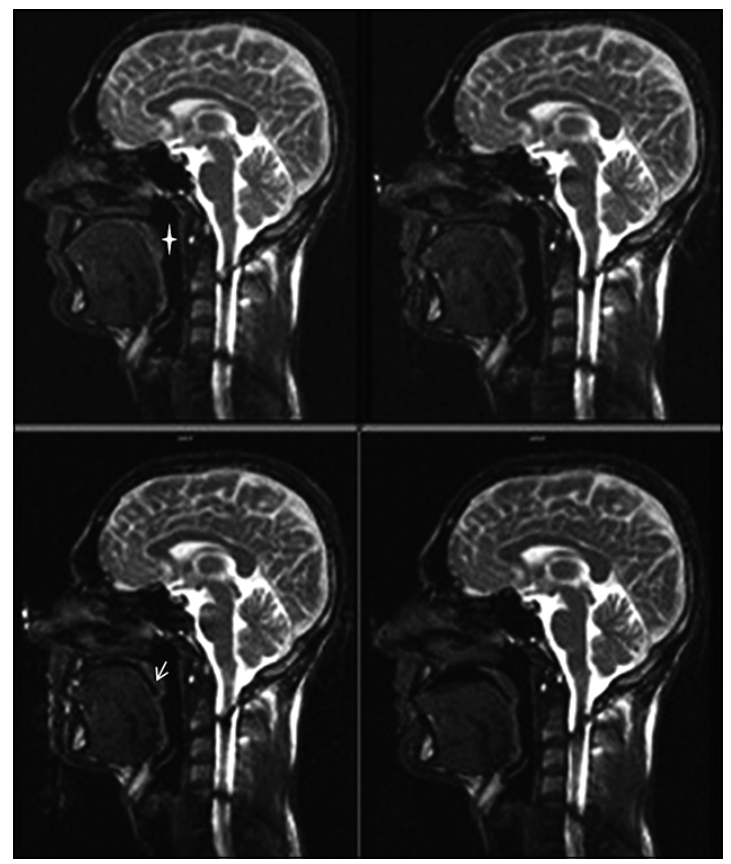

Figure 3. Midsagittal MRI dynamic examination of a control patient. Thickness of uvula(arrow) was normal and posterior airway was wide (asterix).

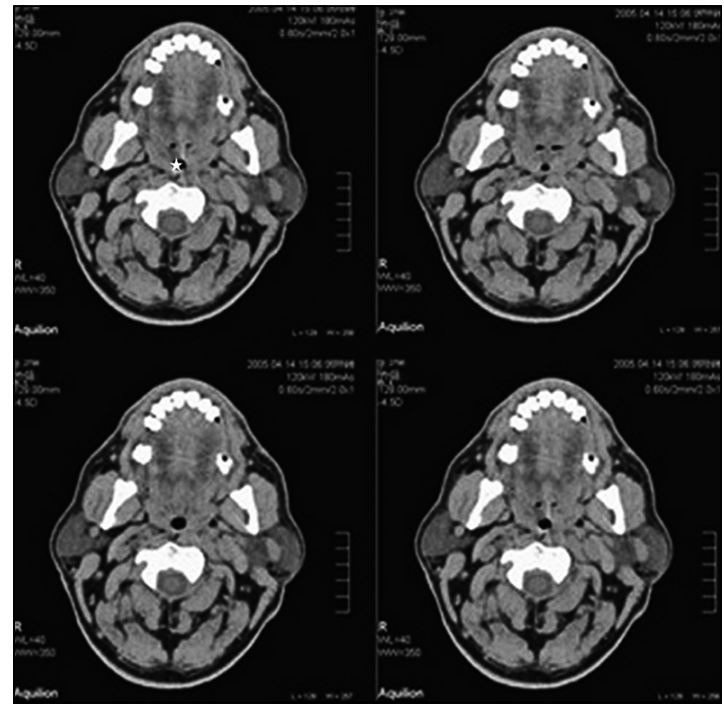

Figure 2. Axial dynamic CT examination of a snoring patient at the oropharynx's narrowest level, oropharynx calibration was narrower than normal (asterix) and wideness significantly decreased while breathing.

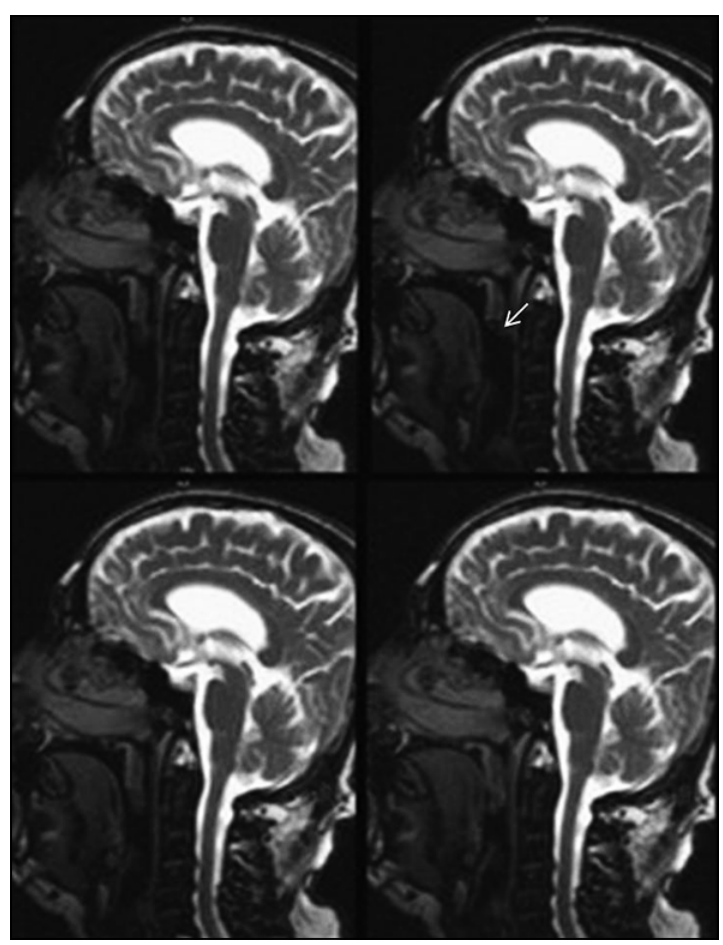

Figure 4. Midsagittal dynamic MRI examination of a snoring patient. During the dynamic examination in which uvula was thick and long, uvula lean against posterior pharyngeal wall (arrow) and there is curling towards posterior in uvula. 
Morphological abnormalities of the pharynx in snoring individuals - F. Aktaş et al

echo (FIESTA) imaging produces imaging sequences quickly. The location at which the uvula was closest to posterior pharyngeal wall, namely where the oropharynx was the narrowest, was identified by observing the uvula's movements during the imaging process. From that position, axial dynamic examination was performed again on 39 image in total (Figure 5, 6). The imaging parameters used in the dynamic examinations were TR of $284.75 \mathrm{msn}$, TE of $1.4 \mathrm{msn}$, FOV of 366 , NEX of 1 , and section thicknesses of $5 \mathrm{~mm}$.

The images were transferred to a study workstation (Leonardo, Siemens Medical Solutions, Forchheim, Germany). At this workstation, the narrow areas of the nasopharynx and the hypopharynx were measured. Posterior airway space (PAS) was measured from the narrowest oropharyngeal area identified using dynamic examination of the midsagittal plane.

Parapharyngeal muscular wall thickness, the parapharyngeal fat pad thickness, anteroposterior (A-P) diameter of the airway, mediolateral (M-L) diameter of the airway, and the narrowest and widest areas of oropharynx were identified using the axial dynamic examinations.

\section{Statistical analyses}

An independent sample t-test was used to show the normal distribution of the data. To compare the patient group and the control group, a Mann-Whitney $U$ test was used for the data that did not show a normal distribution. A Pearson correlation test was used to identify the parameters that affected the areas of the oropharynx.

For the correlation value $r$ in the Pearson correlation test, $0.00-0.24$ was considered a weak correlation, $0.25-0.49$ amedium correlation, 0.50-0.74 a strong correlation, and $0.75-1.00$ was considered a very strong correlation. Multiple regression analysis was used to show the effect of BMI on areas of the neck, neck diameter, and the muscular wall thickness of the parapharyngeal fat pad. The Statistical Package for Social Science (SPSS) software program was used to complete these statistical analyses. P-values lower than 0.05 were accepted as significant.

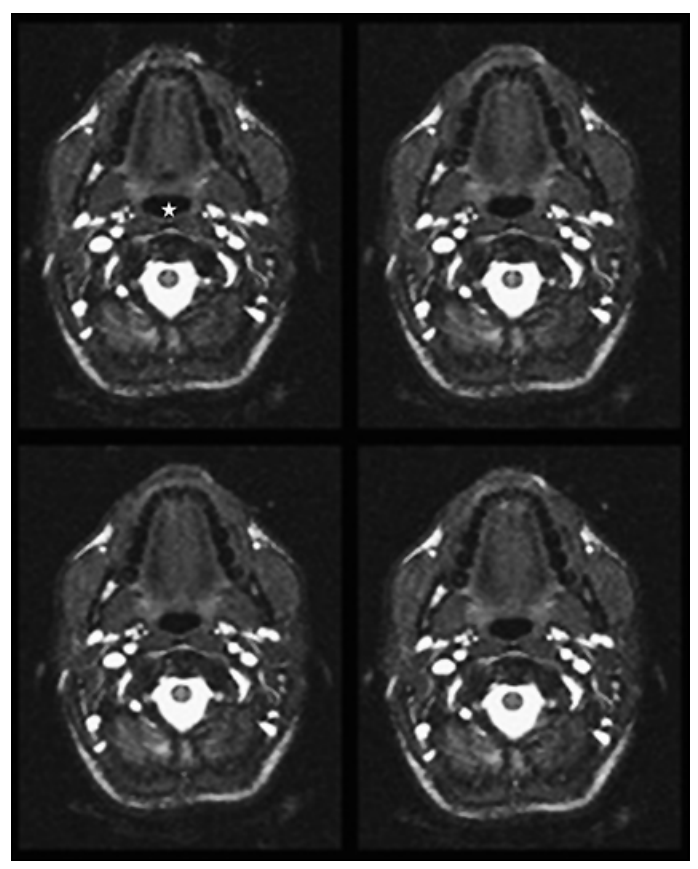

Figure 5. Axial dynamic MRI examination of a control patient at the oropharynx's narrowest level. The airway was not narrow (asterix) and there was not any significant change in airway calibration based on the dynamic examination.

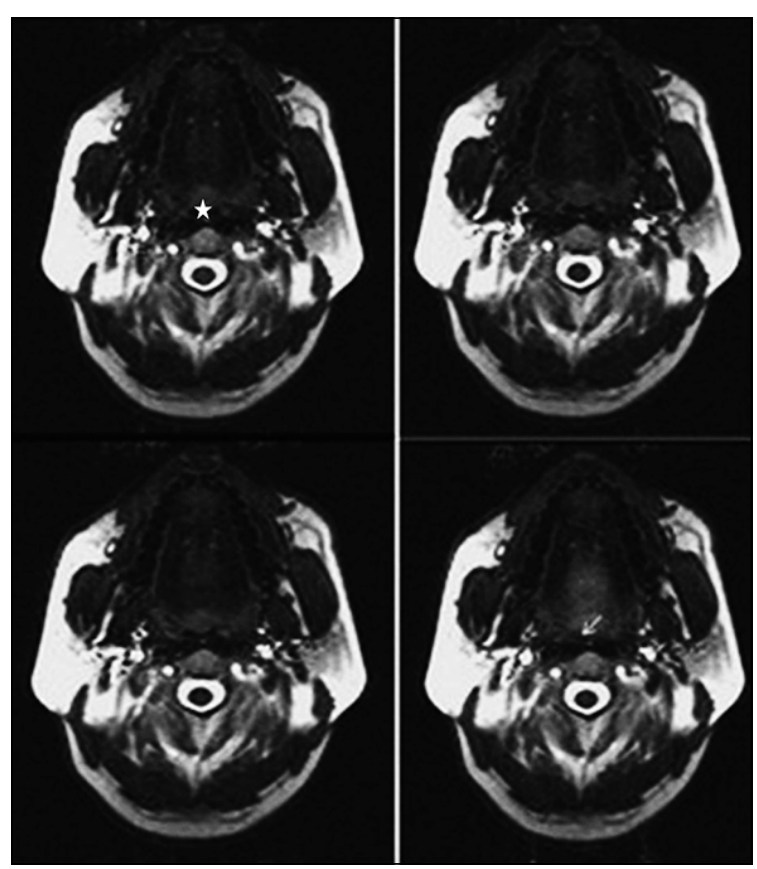

Figure 6. Axial dynamic MRI examination of a snoring patient at the oropharynx's narrowest level. Oropharynx's calibration was significantly narrow (asterix) and according to the dynamic examination, the airway was totally obliterated (arrow). 


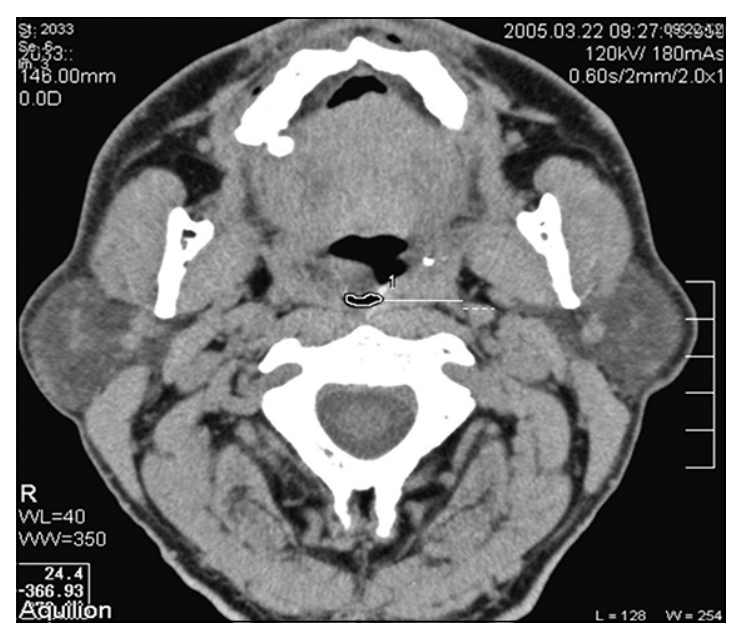

Figure 7. Axial dynamic CT examination of a snoring patient at the oropharynx's narrowest level. Area measurement, parapharyngeal muscular wall thickness (straight line) and parapharyngeal fat pad thickness (dotted line).

\section{Results}

Sixty-four individuals participated in this study. The patient group consisted of 26 males and 12 females. Twenty-six individuals were included in the control group. In the patient group, the average age was 45 , with an average age of 46 in the control group. There were no significant differences in terms of age between the groups.

In the patient group, the average neck diameter was $39 \mathrm{~cm}$. the neck diameter was higher in the patient group $(p=0.032)$. Although there were no significant differences in terms of BMI, the neck diameter of the male participants (which was 39.5 on average) was significantly higher $(\mathrm{p}=0.002)$ than the neck diameter of female participants (which was 34.5 on average). The thickness of the bilateral parapharyngeal fat pad was statistically higher in females. Compared to the control group, the patient group's average BMI (which was 30.35) was significantly higher $(\mathrm{p}=0.001)$ than control group's average BMI (which was 25.08).

Table 1 and 2 presents the averages and the p-values of the patient group and the control group based on evaluations of MRI data. According to the MRI data, the PAS was significantly narrower in the patient group. Muscular thickness of the bilateral parapharyngeal space was significantly greater in the patient group $(\mathrm{p}=0.000)$. However,

Table 1. MRI measurements of all individuals

\begin{tabular}{|c|c|c|c|c|c|}
\hline Parameters & Group & $\mathbf{n}$ & Mean value & Standart deviation & P value \\
\hline \multirow[t]{2}{*}{ PAS } & Patient & 38 & 5.221 & 1.8313 & \multirow[t]{2}{*}{0.000} \\
\hline & Control & 12 & 7.592 & 1.9463 & \\
\hline \multirow[t]{2}{*}{ NP narrowest area } & Patient & 38 & 203.658 & 93.1979 & \multirow[t]{2}{*}{0.000} \\
\hline & Control & 12 & 344.250 & 98.5874 & \\
\hline \multirow{2}{*}{ HP narrowest area } & Patient & 38 & 212.526 & 94.4706 & \multirow{2}{*}{0.011} \\
\hline & Control & 12 & 304.750 & 134.7605 & \\
\hline \multirow[t]{2}{*}{ OP narrowest area } & Patient & 38 & 61.789 & 38.2072 & \multirow[t]{2}{*}{0.000} \\
\hline & Control & 12 & 213.667 & 81.6025 & \\
\hline \multirow[t]{2}{*}{ A-P diameter of OP narrowest area } & Patient & 38 & 5.163 & 2.3693 & \multirow[t]{2}{*}{0.005} \\
\hline & Control & 12 & 7.325 & 1.7576 & \\
\hline \multirow[t]{2}{*}{ M-L diameter of OP narrowest area } & Patient & 38 & 10.934 & 5.0282 & \multirow[t]{2}{*}{0.000} \\
\hline & Control & 12 & 23.800 & 7.5667 & \\
\hline \multirow[t]{2}{*}{ OP widest area } & Patient & 38 & 125.895 & 83.6759 & \multirow[t]{2}{*}{0.000} \\
\hline & Control & 12 & 263.333 & 101.0277 & \\
\hline \multirow{2}{*}{ A-P diameter of OP widest area } & Patient & 38 & 7.555 & 2.7384 & \multirow[t]{2}{*}{0.378} \\
\hline & Control & 12 & 8.317 & 1.9881 & \\
\hline \multirow[t]{2}{*}{ M-L diameter of OP widest area } & Patient & 38 & 13.803 & 5.2628 & \multirow[t]{2}{*}{0.000} \\
\hline & Control & 12 & 25.108 & 7.4123 & \\
\hline
\end{tabular}

OP: oropharynx NP: nasopharynx HP: hypopharynx A-P: anteroposterior M-L: mediolateral PAS: posterior airway space n: patient number. 
no statistical differences between the patient group and the control group were identified in terms of thickness of the parapharyngeal fat pad.

Next, A-P and M-L diameters in the narrowest and widest portions of the oropharynx were compared in both groups. In the patient group, M-L diameter was significantly smaller in the narrowest and widest portions of the oropharynx. However, in the control group, A-P diameter was smaller only in the narrowest area of the oropharynx. According to the correlation test, a very strong relation between $\mathrm{M}-\mathrm{L}$ diameter and the narrowest and widest areas of the oropharynx was identified. A positive correlation between A-P diameter and the narrowest and the widest areas of the oropharynx was also found.
As the thickness of the parapharyngeal muscular wall increased, M-L diameter decreased (a strong correlation). As the narrowest area of the oropharynx increased, the widest area also increased (a strong correlation). Next, the relationship between BMI and the other parameters was measured. As the BMI increased, thickness of the bilateral parapharyngeal fat pad increased at the point at which the oropharynx was the narrowest. As the BMI increased, the oropharynx grew significantly narrower $(\mathrm{p}=0.05)$.

Based on the data from CT images of the patient and control groups, area measurements are presented in Table 3. Oropharynx's the narrowest area was significantly narrow in patient

Table 2. MRI measurements of all individuals

\begin{tabular}{|c|c|c|c|c|c|}
\hline Parameters & Group & $\mathbf{n}$ & Mean value & Standart deviation & P value \\
\hline R-pmt of the narrowest OP area & $\begin{array}{l}\text { Patient } \\
\text { Control }\end{array}$ & $\begin{array}{l}38 \\
12\end{array}$ & $\begin{array}{r}14.329 \\
7.383\end{array}$ & $\begin{array}{l}3.8167 \\
2.2993\end{array}$ & 0.000 \\
\hline R-pft of the narrowest OP area & $\begin{array}{l}\text { Patient } \\
\text { Control }\end{array}$ & $\begin{array}{l}38 \\
12\end{array}$ & $\begin{array}{l}13.955 \\
12.950\end{array}$ & $\begin{array}{l}5.8160 \\
4.8734\end{array}$ & 0.591 \\
\hline L-pmt of the narrowest OP area & $\begin{array}{l}\text { Patient } \\
\text { Control }\end{array}$ & $\begin{array}{l}38 \\
12\end{array}$ & $\begin{array}{r}14.563 \\
8.808\end{array}$ & $\begin{array}{l}3.6351 \\
2.6342\end{array}$ & 0.000 \\
\hline L-pft of the narrowest OP area & Patient & 38 & 14.268 & 5.6545 & 0.844 \\
\hline R-pmtwidest OP area & $\begin{array}{l}\text { Patient } \\
\text { Control }\end{array}$ & $\begin{array}{l}38 \\
12\end{array}$ & $\begin{array}{r}12.947 \\
7.492\end{array}$ & $\begin{array}{l}3.6955 \\
1.8686\end{array}$ & 0.000 \\
\hline R-pft OP widest area & $\begin{array}{l}\text { Patient } \\
\text { Control }\end{array}$ & $\begin{array}{l}38 \\
12\end{array}$ & $\begin{array}{l}13.726 \\
13.600\end{array}$ & $\begin{array}{l}5.7511 \\
5.2263\end{array}$ & 0.946 \\
\hline L-pmt OP widest area & $\begin{array}{l}\text { Patient } \\
\text { Control }\end{array}$ & $\begin{array}{l}38 \\
12\end{array}$ & $\begin{array}{r}13.295 \\
8.042\end{array}$ & $\begin{array}{l}3.4653 \\
1.8952\end{array}$ & 0.000 \\
\hline L-pft OP widest area & $\begin{array}{l}\text { Patient } \\
\text { Control }\end{array}$ & $\begin{array}{l}38 \\
12\end{array}$ & $\begin{array}{l}13.811 \\
14.808\end{array}$ & $\begin{array}{l}5.6845 \\
5.4930\end{array}$ & 0.596 \\
\hline
\end{tabular}

R-pmt: right pharapharyngealmucsle thickness. L-pmt: left pharapharyngealmucsle thickness. R-pft: right pharapharyngeal fat-pad thickness. L-pft: left pharapharyngeal fat-pad thickness.

Table 3. CT measurements

\begin{tabular}{|c|c|c|c|c|c|}
\hline Parameters & Group & $\mathbf{n}$ & Mean value & Standart deviation & P value \\
\hline NP narrowest area & $\begin{array}{l}\text { Patient } \\
\text { Normal }\end{array}$ & $\begin{array}{l}38 \\
14\end{array}$ & $\begin{array}{l}298.908 \\
243.571\end{array}$ & $\begin{array}{r}113.3140 \\
93.2942\end{array}$ & 0.109 \\
\hline HP narrowest area & $\begin{array}{l}\text { Patient } \\
\text { Normal }\end{array}$ & $\begin{array}{l}38 \\
14\end{array}$ & $\begin{array}{l}270.826 \\
218.000\end{array}$ & $\begin{array}{r}124.8289 \\
77.3812\end{array}$ & 0.076 \\
\hline OP narrowest area & $\begin{array}{l}\text { Patient } \\
\text { Normal }\end{array}$ & $\begin{array}{l}38 \\
14\end{array}$ & $\begin{array}{r}88.961 \\
147.071\end{array}$ & $\begin{array}{l}61.9949 \\
43.0911\end{array}$ & 0.002 \\
\hline OP widest area & $\begin{array}{l}\text { Patient } \\
\text { Normal }\end{array}$ & $\begin{array}{l}38 \\
14\end{array}$ & $\begin{array}{l}148.316 \\
195.643\end{array}$ & $\begin{array}{r}108.9634 \\
60.7892\end{array}$ & 0.132 \\
\hline
\end{tabular}

OP: oropharynx NP: nasopharynx HP: hypopharynx. 
group. MRI and CT measurements were applied to patient and control group at approximately same level. When MRI and CT measurements are compared, strong correlation for oropharynx's the widest area and medium level correlation for the other area measurements were found.

\section{Discussion}

Snoring, the most frequently identified symptom of OSAS, affects $10-12 \%$ of global society. Snoring can cause serious clinical problems that may result in death ${ }^{2}$. OSAS is seen in $2 \%$ of females and $4 \%$ of males. Cases of OSAS can reach $30 \%$ in individuals with obesity and between 50 and $98 \%$ in those with morbid obesity ${ }^{3}$. In patients with untreated OSAS, the risk of fatality increases 2.9 times; the nonfatality risk increases 3.2 times $^{4}$.

Polysomnography is ideal for diagnosing OSAS . However, not all medical professionals are able to use this method. Because polysomnography requires a fully equipped sleep laboratory with sophisticated equipment and a trained technician, this method can create long wait times prior to treatment. OSAS is a common disease, which suggests that more simple diagnostic methods should be developed ${ }^{6}$. Various methods, such as fluoroscopy, nasopharyngoscopy, cephalometry, $\mathrm{CT}$, and MRI, can be used to identify abnormalities in the upper airways of patients who snore. This paper evaluates the causes of upper airway obstruction and confirms whether differences exist between MRI and CT (two common methods used to show abnormalities in upper airways).

Activities of the palate, tongue, and pharyngeal dilator muscles cause airways to dilate ${ }^{7}$. Many studies have demonstrated that the airway is anatomically smaller in snorers and OSAS patients. In many studies, the most affected area in patients with sleep apnea is the retropalatal region of the oropharynx $^{8-10}$. It is stated in the study of Ahn et al. one of the reasons of narrowness in retropalatal area was increase in volume of tongue ${ }^{11}$. Some studies suggest that airway collapse and apnea occur due to increased movement of the pharyngeal structures, rather than anatomical obstruction. In the present study, dynamic evaluation of the retropalatal region of the oropharynx (the narrowest region) was performed. This study concludes that all pharyngeal areas are narrower when compared to the MRI results of the control group. The narrowest section is the retropalatal region of the oropharynx in both MRI and CT. This finding agrees with previous literature on the topic. Referring to patients with severe OSAS, Avrahami et al. state that the narrowest section of the oropharynx is less than $50 \mathrm{~mm}^{2}$ during bradypnea $^{12}$. In the present study, the narrowest section of the oropharynx measure is $61.789 \pm$ $38.2072 \mathrm{~mm}^{2}$ in MRI and $88,961 \pm 61,9949 \mathrm{~mm}^{2}$ in CT inthe patient group. Therefore, the oropharynx is significantly narrower in patients who have issues with snoring compared to individuals from the control group. but oropharynx is larger than patients with OSAS. This makes OSAS easy to diagnose.

Obesity, which can be easily diagnosed through a physical examination, is the most important factor in determining whether an individual will be affected by snoring and OSAS ${ }^{3}$.

Researchers have demonstrated that BMI is significantly higher in patients who snore ${ }^{13}$. The present study confirms that BMI and neck diameter are significantly higher in the patient group. Other studies have demonstrated that the parapharyngeal fat pad is larger in patients affected by snoring and apnea. They think the parapharyngeal fat pad narrows the airway by compressing the lateral walls. Alternatively, Akan et al. suggest that airway obstruction primarily depends on M-L diameter in patients affected by snoring ${ }^{7}$. In the present study, no significant differences in thickness of the parapharyngeal fat pad have been found between the two groups. So the parapharyngeal fat tissue does not influence airway obstruction, nor does this tissue narrow the airway by compressing the lateral pharyngeal wall. Rather, parapharyngeal fat tissue is easily compressed by the lateral pharyngeal wall ${ }^{7}$. This study indicates that parapharyngeal muscle thickness changes, though fat pad thickness does not change during dynamic evaluation. Parapharyngeal muscle thickness is significantly higher in the patient group in dynamic evaluation of the airways $(p=0.000)$.

Many studies have been performed to observe the physiopathology and anatomical differences in patients with OSAS and snorers. The most frequently used imaging methods are CT and MRI. There is not a study in literature that compared MRI and CT findings of patients with OSAS and snorers. Thus, it is unknown that which method 
provides the most accurate results. We made measurements of same localizations in same patient group. However, when the findings were compared, there wasn't strong correlation between other parameters except the largest oropharyngeal area. When all of the studies in literature that had been performed with MRI and CT were considered, the common conclusion is that oropharynx; especially the retropalatal region was narrow in patients. This indicates that the most important zone was retropalatal region of oropharynx in snoring and OSAS.

We observed that the mean lumen area of the narrowest section of oropharynx was $61 \mathrm{~mm}^{2}$ in MRI and $88 \mathrm{~mm}^{2}$ in CT. Actually all areas were narrower in MRI. This may be related with the slight surge towards airway during measurements due to unclear margins between air in the pharynx and pharyngeal wall that MRI provided. Besides, as another reason; we had firstly determined the narrowest oropharyngeal section via mid-sagittal dynamic imaging, and then we performed axial dynamic examination. Hence the CT imaging didn't provide sagittal dynamic imaging; we determined the narrowest level from lateral scenography and routine axial images. Therefore, the level that was determined with MRI may be more accurate and the results may be narrower.

The reason of different results of fat pad and muscle thicknesses may be the better discrimination of fat and muscle tissue in MRI images when compared with CT. Thus, MRI is more effective in this subject. Additionally, MRI shows fat deposition in different localizations like tongue, soft palate and retropharyngeal region and tonsillar hypertrophy better than CT. All measurements that can be achieved via CT can also be made with MRI, the narrowest section can be determined, additionally multiplanar images can be obtained and pathologic fat deposits can be visualized. Also, it doesn't contain ionizing radiation.

There are some limitations in this study. The patient group included in the study had snoring problem, however it was not known that if the patients had OSAS since polisomnography was not used systematically. The second limitation was that the number of patients low. Moreover, it is known that there is relaxation in the muscles providing the airway patency during the sleep and for this reason, airway gets narrower while sleeping. We applied both MRI and CT examinations while the patients were awake.

In conclusion, the researchers evaluated changes in the upper airway and other factors that play a role in snoring. This study produced accurate results by comparing MRI and CT images of those affected by snoring (the patient group) and individuals that do not have this condition (the control group). The following major conclusions can be made: 1) The narrowest section of the airway is the retropalatal region of the oropharynx. This finding was produced using both imaging techniques; 2 ) Neck diameter is greater in patients who snore and are affected by apnea compared to individuals in the control group. In addition, neck diameter is greater in men than in women; 3) BMI levels are higher in individuals that snore; 4) The oropharynx becomes narrower in those with obesity; 5) Thickness of the parapharyngeal fat pad does not aggravate snoring. However, parapharyngeal muscle thickness is higher in those that snore. The oropharynx also narrows as parapharyngeal muscle thickness increases.

\section{References}

1. Fairbanks D. Snoring: An overview with historical perspectives. In: DN Fairbanks, S Fujita (ed.) Snoring and obstructive sleep apne (2nd ed.) Washington, Rave Press 1994; 1: 1-16.

2. Olszewska E, Sieskiewicz A, Rozycki J, Rogalewski M, Tarasow E, Rogowski M, et al. Comparison of cephalometric analysis using radiographs and craniofacial computed tomography in patients with obstructive sleep apnea syndrome: preliminary report. Eur Arch Otorhinolaryngol 2009; 266 (4): 535-42.

3. Redline S, Tishler PV, Schluchter M, Aylor J, Clark K, Graham G. Risk factors for sleep-disordered breathing in children: associations with obesity, race, and respiratory problems. Am J Respir Crit Care Med 1999; 159: 1527-32.

4. Practice Committee of the American Sleep Disorders Association. Practice parameters for the indications for polysomnography and related procedures. Sleep 1997; 20: 406-22.

5. ATS/ACCP/AASM Taskforce Steering Committee. Executive summary on the systematic review and practice parameters for portable monitoring in the investigation of suspected sleep apnea in adults. Am J Respir Crit Care Med 2004; 169: 1160-3.

6. Akan H, Aksöz T, Belet U, Sesen T. Dynamic upper 
airway soft-tissue and caliber changes in healthy subjects and snoring patients. AJNR Am J Neuroradiol 2004; 25 : 1846-50.

7. Gold AR, Schwartz AR, Wise RA, Smith PL. Pulmonary function and respiratory chemo sensitivity in moderately obese patients with sleep apnea. Chest 1993; 103: 1325-9.

8. Katsantonis GP, Moss K, Miyazaki S, Walsh J. Determining the site of airway collapse in obstructive sleep apnea with airway pressure monitoring. Laryngoscope 1993; 103: 1126-31.

9. Shigeta Y, Ogawa T, Tomoko I, Clark GT, Enciso R. Soft palate length and upper airway relationship in OSA and non-OSA subjects. Sleep Breath 2010; 14 (4): 353-8.

10. Ahn SH, Kim J, Min HJ, Chung HJ, Hong JM, Lee JG, et al. Tongue Volume Influences Lowest Oxygen Satu- ration but Not Apnea-Hypopnea Index in Obstructive Sleep Apnea. PLoS One 2015; 10 (8): e0135796. doi: 10.1371/

11. Avrahami E, Englender M. Relation between CT axial cross-sectional area of the oropharynx and obstructive sleep apnea syndrome in adults. AJNR Am J Neuroradiol 1995; 16: 135-40.

12. Mayer P, Pepin JL, Bettega G, Veale D, Ferretti G, Deschaux C, et al. Relationships between body mass index, age and upper airway measurements in snorers and sleep apnea patients. Eur Respir J 1996; 9: 1801-9.

13. Horner RL, Mohiaddin RH, Lowell DG, Shea SA, Burman FD, Longmore DB, et al. Sites and size of fat depositis around the pharynx in obese patients with obstructive sleep apnea and weight matched control. Eur Respir J 1989; 2: 613-22. 